\title{
Cephalometric norms for a sample of Emirates adults
}

\author{
${ }^{1}$ Faculty of Oral and Dental Medicine, Cairo University, Cairo, Egypt;
${ }^{2}$ Ministry of Health, Sharjah, United Arab Emirates.
Email: ${ }^{*}$ huda ma@hotmail.com
}

Huda M. Abu-Tayyem ${ }^{1 *}$, Amna H. Alshamsi ${ }^{2}$, Sayed Hafez ${ }^{1}$, Eman Mohie EIDin ${ }^{1}$

Received 23 May 2011; revised 21 July 2011; accepted 3 August 2011.

\section{ABSTRACT}

Introduction: European-American norms are still used in the orthodontic treatment of Emirates patients despite the different ethnic backgrounds of the Emirates. The purpose of this study was to formulate cephalometric norms for lateral cephalometric measurements of Emirates adults and to study gender differences. Methods: Lateral cephalometric radiographs of 176 Emirates adults, 91 males and 85 females, were selected according to the following criteria; an age range between 19 to 25 years, esthetically pleasing and harmonious faces with balanced and acceptable profiles and occlusions, normal skeletal and dental relationship, all permanent teeth present, and no history of orthodontic treatment or facial trauma. The mean values and standard deviations of 91 angular and 21 linear cephalometric variables were calculated using the Dolphin version 10.5 software package. The resulting norms for Emirates male and female groups were compared using a student t-test. Results: Several statistically significant gender differences were noticeable. Skeletally, Emirates males showed significantly greater $(p<0.001)$ total, anterior, and posterior cranial base lengths as well as longer facial heights, greater SGn-FH $\left({ }^{\circ}\right)$, ANS Xi PM ( $\left(^{\circ}\right.$ ), and FH/MP ( ${ }^{\circ}$ ) angles than females. In addition, Emirates males had significantly greater ( $p$ $<0.001)$ Co-A (mm), Co-Gn (mm), and significantly greater $(p<0.05)$ Pog-N vert $(\mathrm{mm})$ than females. Dentally, Emirates males had significantly greater ( $p$ $<0.05)$ UI-SN $\left({ }^{\circ}\right)$ and U1-NA $\left({ }^{\circ}\right)$, U1-NA (mm), and L1-NB (mm) $(p<0.001)$ than females. For soft tissue measurements there were significant gender differences $(p<0.001)$ for all angular and linear measurements except for lower lip to E-plane and nose prominence measurements which have no significant gender difference. Emirates males revealed greater measurements than females except for soft tissue convexity, $Z$-angle, and both upper and lower lips pro- trusion which were significantly greater in Emirates females. Conclusions: The use of specific cephalometric standards for Emirates adults, separate for gender, seems to be justified. It is appropriate to put these cephalometric norms into daily orthodontic practice when Emirates adults are being treated.

Keywords: Emirates Norms; Cephalometric; Norms

\section{INTRODUCTION}

Since its introduction in 1931 by Broadbent [1] and Hofrath [2] in the United States and Germany, respectively, radiographic cephalometry has become one of the most important tools of clinical and orthodontic research [3]. Cephalometric norms provide useful guidelines to orthodontists in their diagnosis and evaluation of orthodontic treatment outcomes. Moreover their importance exists to investigate the average values, shapes and variations among any population [4].

Harmonious facial esthetics and optimal functional occlusion have long been recognized as the most important goals of orthodontic treatment. Orthodontic treatment is best when the facial and cephalometric characteristics of the ethnic background of patients are considered $[4,5]$. The orthodontic literature contains many studies involving cephalometric and profile standards of Caucasian and European-American [5-15], AfricanAmerican [16-24], Japanese [25-29], Chinese [30-33], Polish [34], Filipinos [35], Mexican-Americans [36], Korean [37,38], Turkish populations [39-42], Indians [43], Brazilians [44], and Puerto Rican Americans [45], but little published data for Arabs [46-58] and non for Emirates in specific. This information is considered as a critical base which should be used for studying growth, diagnosis, treatment planning and prognosis of such population.

Hajighadimi et al. [46] studied craniofacial characteristics of 67 Iranian children (35 females with and 32 
males) using Tweed and Steiner analyses. They reported that Iranians have a more convex soft tissue profile compared with Tweed's and Steiner's standards; whereas Iranian males had more procumbent dentitions than the female one. Bishara et al. [49] established cephalometric standards for Egyptian adolescent males and females and compared them with a matched Iowa adolescent sample. There was a great similarity in the overall facial morphology between the Egyptian and Iowan populations. Hamdan and Rock [51] evaluated the cephalometric features of a Jordanian population as compared with the Eastman standards and found different skeletal and dental cephalometric features for the Jordanians. Shalhoub et al. [52] evaluated lateral cephalometric radiographs of 48 adult Saudis with normal facial proportions, compared them with a North American sample, and established a set of cephalometric norms for Saudi adults living in Riyadh. Sarhan and Nashashibi [53] compared cephalometric radiographs of Saudi males (10 - 14 years old) with a similar British sample. They found slightly more prognathic Saudi faces, more protruded incisors and lower gonial and saddle angles as compared with the British sample.

Al-Jasser [54] described the craniofacial characteristics of 87 Saudi students with acceptable profiles and occlusions and compared them with Steiner's European-American standards. It was concluded that Saudis have different craniofacial features when compared with Steiner norms. Al-Jame et al. [55] studied lateral cephalograms of 162 Kuwaitis (82 males and 80 females of mean age $13.27 \pm 0.42$ years and $13.21 \pm 0.43$ years, respectively), with normal occlusion to establish lateral cephalometric hard tissue norms and to compare them with the published norms. They found that the average subject in the sample had a steeper mandibular plane, a more convex profile with a tendency for reduced chin protrusion, and a more protrusive dentition than the norms of the common analysis systems. Hassan [56] evaluated 70 lateral cephalometric radiographs of Saudis (32 females and 38 males; aged 18 - 28 years) with acceptable profiles and occlusions living in the western region of Saudi Arabia and compared them with European-American norms. He found that Saudis tended to have an increased ANB angle because of retrognathic mandibles and bimaxillary protrusion as compared with European-Americans. Hashim and AlBarakati [57] evaluated cephalometric radiographs of 56 Saudi adults (30 males and 26 females) with pleasant and balanced facial profiles. The Saudi females had a greater angle of total facial convexity and soft tissue facial plane angle and a shorter lower lip than the males. Their results revealed significant differences in most of the soft tissue variables when comparing Saudis with Caucasian Americans as well as in other ethnic groups. Al-Gunaid et al. [58] studied 50 adult Yemeni men (with a mean age was 23.1 years) with normal occlusion and esthetically pleasing profile and compared them with cephalometric standards of normal North American white people according to Legan-Burstone and Holdaway analyses. They concluded that soft-tissue facial profiles of white Yemenis and Americans are different in certain respects and these racial differences must be considered during diagnosis and treatment planning.

From this review, it can be concluded that there are differences in dentofacial relationships between various ethnic and racial groups. Therefore, it is important to develop standards for various populations. Accordingly, the present study was concerned with an ethnic group for which little cephalometric information was available, the Emirates adults. The purpose of this study was to formulate cephalometric norms for the Emirates adults with acceptable facial profile and occlusion and to study gender differences.

\section{MATERIAL AND METHODS}

This study was carried out on a total sample of 176 Emirates adults (91 males and 85 females) selected from individuals who attended the Emirates health centers, high schools and colleges according to the following criteria: natural born ethnic Emirates with Emirates grandparents, ranged in age from 19 to 25 years old, balanced and acceptable facial profiles, normal skeletal Class I with well aligned upper and lower dental arches, permanent dentition stage (the third molars may or may not be present), no history of previous orthodontic or prosthodontic treatment, no history of maxillofacial or plastic surgery, no congenital facial anomalies, and no history of systemic diseases or chronic illness that may affect the normal dentofacial growth.

Initially, a clinical examination was made to determine the status of the occlusion, and those subjects who were judged to have a normal occlusion were selected. The procedure of selecting subjects started with filling personal information by the subject. Then three examiners, including two orthodontists and one postgraduate orthodontic student, examined overjet, overbite, crowding, and spacing condition of the teeth. Two hundred subjects met these criteria in the preliminary examination and were asked to report to the Department of Orthodontics, Sharjah Dental Center, Ministry of Health, Sharjah, United Arab Emirates for a more detailed examination. Of these 200 subjects, 24 chose not to participate in the study. A closer examination of the subjects indicated that 15 had different types of malocclusion, and another 9 were either older or younger than the age 
range specified for this investigation. As a result, a total of 176 Emirates adults (91 males and 85 females) were included in the present study. Informed consents were obtained from all subjects involved in the study. Al Qassimi Hospital research Ethics Committee (Ministry of Health, United Arab Emirates) had reviewed the research proposal and approved it.

A lateral cephalometric X-ray was taken for each subject using a cephalometric X-ray machine (Planmeca Proline XC system, Helsinki, Fenland, at IBIN SINA Medical Center, United Arab Emirates) according to Broadbent method [1]. The subject's head was held in the so called natural head position (mirror position) [59-61]. All the subjects were radiographed with the same machine to standardize the magnification. Anatomic landmarks were identified directly on the digital images and 21 linear and 19 angular cephalometric measurements were calculated electronically using the Dolphin version 10.5 software package (Dolphin imaging and management solutions version 10.5, Eton Avenue, Chatsworth, USA). Landmarks identification (Figures 1 and 2) and measurements of the cephalometric radiographs were made by a single author (H.M.) and reviewed twice by other investigators. All measurements were taken to the nearest 0.5 millimeters and degrees.

\section{Cephalometric Measurements [3,39,42,49]:}

Skeletal angular and linear measurements:

1) S-N (mm) (Anterior cranial base length): the horizontal distance from sella turcica and anterior point of the frontonasal suture.

2) S-Ar ( $\mathrm{mm})$ (Posterior cranial base length): the horizontal distance from sella turcica and articulare.

3) Ba-N (mm) (Total cranial base length): the horizontal distance from basion to nasion.

4) $\mathrm{FH} / \mathrm{SN}\left({ }^{\circ}\right)$ : It represents the inclination of the anterior cranial base.

5) N-Me (mm) (Total anterior facial height): the linear distance between nasion $(\mathrm{N})$ and menton $(\mathrm{Me})$.

6) N-ANS (mm) (Upper anterior facial height): the linear distance between nasion $(\mathrm{N})$ and anterior nasal spine (ANS).

7) ANS-Me (mm) (Lower anterior facial height): the linear distance between anterior nasal spine (ANS) and menton $(\mathrm{Me})$.

8) S-Go ( $\mathrm{mm})$ (Total posterior facial height): the linear distance between sella point (S) and gonion (Go).

9) $\mathrm{SGn} / \mathrm{FH}\left({ }^{\circ}\right)$ (Y-axis angle): the lower and anterior angle of the intersection of Y-axis (S-Gn) and the Frankfort horizontal plane. It represents the direction of the mandibular growth in relation to the face.

10) ANB $\left({ }^{\circ}\right)$ : the difference between SNA and SNB angles, and defines the mutual relationship, in the sagittal

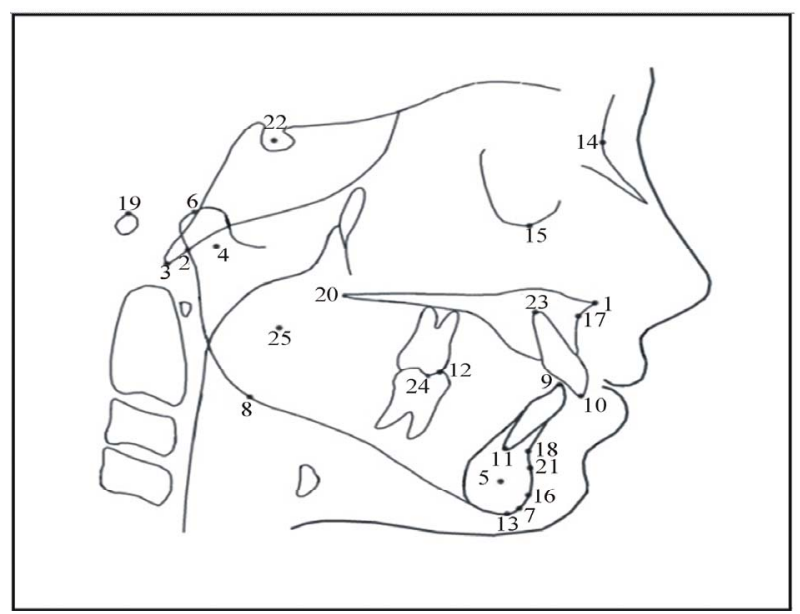

Figure 1. Cephalometric reference points, hard tissue landmarks. 1, Anterior nasal spine (ANS); 2, Articulare (Ar); 3, Basion (Ba); 4, Condylion (Co); 5, Gnathion (Gn); 6, Gonion (Go); 7, Incisor inferius (Ii); 8, Incisor superius (Is); 9, L1 root; 10, Lower 6 occlusal (L6); 11, Menton (Me); 12, Nasion (N); 13, Orbitale (Or); 14, Pogonion (Pog); 15, Subnasale (Point-A); 16, Supramental (Point-B); 17, Porion (Po); 18, Posterior nasal spine (PNS); 19, Protuberance menti (PM); 20, Sella Turcica (S); 21, U1 root; 22, Upper 6 occlusal (U6); 23, Xi point (Xi).

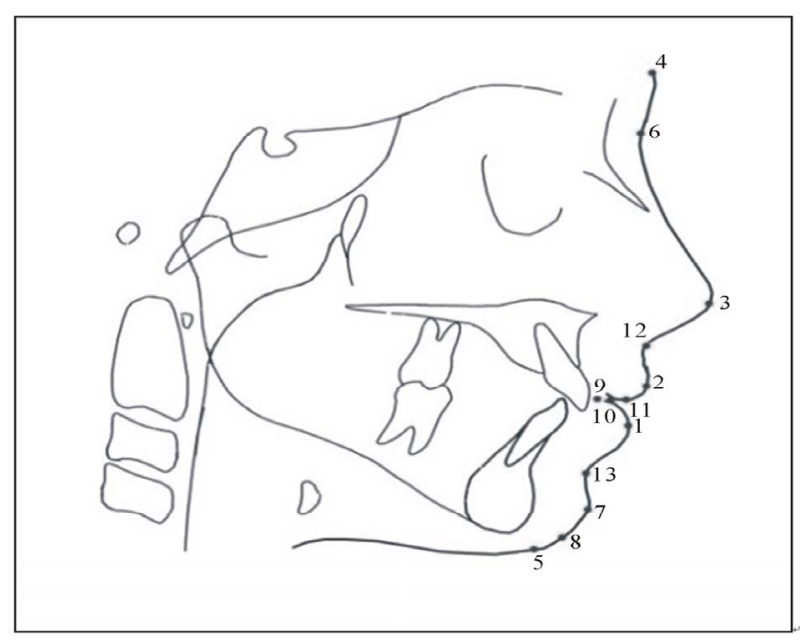

Figure 2. Cephalometric reference points, soft tissue landmarks. 1, Labrale inferius (Li); 2, labrale superius (Ls); 3, Pronasale (Pn); 4, Soft tissue glabella (G'); 5, Soft tissue menton (Me'); 6, Soft tissue nasion (N'); 7, Soft tissue pogonion (Pog'); 8, Soft tissue gnathion (Gn'); 9, Stomion (Sto); 10, Stomion inferius (Stoi); 11, Stomion superius (Stos); 12, Subnasale $(\mathrm{Sn}) ; 13$, Supramentale $(\mathrm{Sm})$.

plane of the maxillary and mandibular bases in relation to the cranium.

11) Ao-Bo/FH (mm): the horizontal distance between two perpendiculars dropped from points $\mathrm{A}$ and $\mathrm{B}$ onto FH plane, measuring the anteroposterior relation of the maxillary and mandibular bases relative to the face.

12) Ao-Bo (mm) (Wit's appraisal): the horizontal dis- 
tance between perpendicular lines from point $\mathrm{A}$ and $\mathrm{B}$ onto the functional occlusal plane, measuring the anteroposterior relation of the maxillary and mandibular bases relative to the functional occlusal plane.

13) FH/MP ( ${ }^{\circ}$ ) (Frankfort mandibular plane angle): the angle formed between Frankfort horizontal plane and mandibular plane.

14) $\mathrm{PP} / \mathrm{SN}\left({ }^{\circ}\right)$ (Palatal plane angle): the angle formed between anterior cranial base (S-N) and palatal plane (PP). It represents the cant of the maxillary plane in relation to anterior cranial base.

15) MP/SN $\left({ }^{\circ}\right)$ : the angle formed between the mandibular plane (Go-Gn) and the anterior cranial base (SN line). It represents the inclination of the mandibular base to the cranium.

16) ANS Xi PM ( ${ }^{\circ}$ ) (Lower face height): this is the angular measurement formed by the intersection of a line from anterior nasal spine to the center of the ramus and the corpus axis. It represents the vertical jaw relation i.e. the depth of the bite.

17) SNA $\left({ }^{\circ}\right)$ : anteroposterior position of the maxilla (apical base) relative to the anterior cranial base.

18) Co-A (mm): the horizontal distance between condylion and point-A. It represents the effective maxillary length.

19) SNB $\left({ }^{\circ}\right)$ : measuring the anteroposterior position of the mandibular base in relation to the cranium.

20) Pog-Nv (mm): the linear distance between the point Pog and a vertical line drawn from nasion perpendicular onto the FH plane. It represents the anteroposterior position of the mandibular chin in relation to the face.

21) Co-Gn (mm): the horizontal distance between condylion and point gnathion. It represents the effective mandibular length.

Dental angular and linear measurements:

22) $\mathrm{U} 1 / \mathrm{L} 1\left(^{\circ}\right)$ (Inter-incisal angle): the angle between long axes of the upper and lower central incisors.

23) U1/SN $\left({ }^{\circ}\right)$ : the angle formed between the long axis of upper central incisor and the anterior cranial base. It represents the degree of the inclination of upper incisors relative to the cranium.

24) U1/NA $\left({ }^{\circ}\right)$ : the angle formed between the long axis of upper central incisor and the NA line. It represents the degree of the inclination of upper incisors relative to the anterior limit of the maxillary base.

25) U1-NA (mm): the linear perpendicular distance from the incisal tip of the most protruded upper central incisor and the N-A line. It represents the degree of the protrusion of upper incisors relative to the anterior limit of the maxillary base.

26) L1-NB (mm): the linear perpendicular distance from the incisal tip of the most protruded lower central incisor and the N-B line. It represents the degree of the protrusion of lower incisors relative to the anterior limit of the mandibular base.

27) $\mathrm{L} 1 / \mathrm{NB}\left({ }^{\circ}\right)$ : the angle between long axis of lower central incisor and NB line. It represents the degree of the inclination of lower incisors relative to the mandibular base.

28) L1/MP $\left({ }^{\circ}\right)$ : the angle between long axis of lower central incisor and the mandibular plane. It represents the degree of the inclination of lower incisors relative to the mandibular base.

Soft tissue angular and linear measurements:

29) H-angle: the angle between soft tissue labrale superious, soft tissue nasion and Pog'. It represents the prominence of the upper lip in relation to N'pog' line.

30) Z-angle: the angle between soft tissue labrale superious, pogonion (profile line) and Frankfort horizontal plane. It represents the amount of lip protrusion.

31) N'SnPog' ( $\left(^{\circ}\right)$ (soft tissue profile): It represents the degree of soft tissue convexity regardless the nose prominence.

32) N'PnPog' $\left({ }^{\circ}\right)$ (soft tissue convexity): It represents the degree of soft tissue convexity including the nose.

33) $\mathrm{PnN}$ 'Sn $\left({ }^{\circ}\right)$ (Nasal prominence): It represents the degree the nasal prominence.

34) Sn-Stos (mm) (length of upper lip): the length of the upper lip measured between subnasale and stomion superius.

35) Stoi-Sm (mm) (length of lower lip): the length of the lower lip measured between stomion and mentolabial sulcus.

36) Ls-E line ( $\mathrm{mm})$ : The horizontal distance between labrale superious and esthetic line. It represents the relative protrusion of the upper lip to the esthetic line.

37) Li-E line ( $\mathrm{mm})$ : The horizontal distance between labrale inferius and esthetic line. It represents the relative protrusion of the lower lip to the esthetic line.

38) Pog-Pog' (mm) (thickness of the soft tissue chin): the horizontal distance between the hard and soft tissue pogonion.

39) Ls-SnPog' (mm) (upper lip protrusion): The horizontal distance between the most anterior point of the upper lip and subnasale soft tissue pogonion line. It represents the relative protrusion or retrusion of the upper lip to the SnPog' line.

40) Li-SnPog' (mm) (lower lip protrusion): The horizontal distance between the most anterior point of the lower lip and subnasale soft tissue pogonion line. It represents the relative protrusion or retrusion of the lower lip to the SnPog' line.

\section{RESULTS}

Means and standard deviations of cephalometric measurements for Emirates adults are shown in Table 1. A 
student t-test was used to compare males with females.

Concerning the cranial base and facial skeleton measurements, there were highly significant gender differences $(p<0.001)$ of the total, anterior, and posterior cranial base lengths which were greater in Emirates males than females. While cranial base tipping is significantly greater $(p<0.05)$ in females than males. Emirates males showed significantly longer $(p<0.001)$ facial heights and greater SGn-FH $\left({ }^{\circ}\right)$ than females.

Regarding the jaw relation there were no significant gender differences for anteroposterior measurements except for the Wit's appraisal $(p<0.05)$ which was greater in Emirates females than males. Whereas ANS $\mathrm{Xi} \mathrm{PM}\left(^{\circ}\right)$ and FH/MP $\left(^{\circ}\right)$ were significantly greater $(\mathrm{p}<$ $0.001)$ in males than females, the SN-PP $\left(^{\circ}\right)$ was significantly greater $(p<0.001)$ in females than males. The rest of jaw relation measurements showed no significant gender difference.

No significant gender difference were reported for SNA while Emirates males had highly significantly greater $(\mathrm{p}<0.001)$ Co-A $(\mathrm{mm})$, Co-Gn $(\mathrm{mm})$, and significantly greater $(\mathrm{p}<0.05)$ Pog-N vert $(\mathrm{mm})$ than females.

Regarding the dental measurements, Emirates males have significant greater $(\mathrm{p}<0.05) \mathrm{UI-SN}\left({ }^{\circ}\right)$ and U1-NA $\left({ }^{\circ}\right)$, U1-NA $(\mathrm{mm})$, and highly significantly greater $(\mathrm{p}<$ $0.001) \mathrm{L} 1-\mathrm{NB}(\mathrm{mm})$ than females whereas U1-L1 $\left(^{\circ}\right)$, L1-NB $\left({ }^{\circ}\right)$, and L1-MP $\left({ }^{\circ}\right)$ show no significant gender difference.

For soft tissue measurements there was significant gender difference for all angular and linear measurements except for lower lip to E-plane and nose prominence measurements which have no significant gender difference. Soft tissue profile angle and soft tissue convexity, both upper and lower lips length, and both upper and lower lips protrusion showed highly significant gender difference $(\mathrm{p}<0.001)$. The facial convexity, H-angle, Z-angle, upper lip to E-plane ( $\mathrm{mm}$ ) and the thickness of soft tissue chin had significant gender difference $(p<0.05)$. Emirates males revealed greater measurements than females except for soft tissue convexity, Z-angle, and both upper and lower lips protrusion which were greater in Emirates females.

\section{Analysis of the Experimental Error}

To determine the errors associated with radiographic measurements, 40 radiographs were selected randomly. Their tracings and measurements were repeated by the same researcher three weeks after the first measurements. Random error was calculated with Dahlberg's formula and the systematic error was detected by comparison of measurements by the paired t-test at a significance level of $5 \%$. Dahlberg's formula $=\sqrt{\sum d \wedge 2 / 2 n}$ where $d$ is the difference the measurements and $n$ is the number of duplicates. The method error was considered negligible (ranged from $0.35^{\circ}$ to $0.44^{\circ}$ for angular cephalometric measurements and from 0.15 to $0.48 \mathrm{~mm}$ for linear measurements). A paired t-test was applied to the first and second measurements, and the differences between the measurements were insignificant. Correlation analysis applied to the same measurements showed the highest $\mathrm{r}$ values for most of the measurements.

\section{DISCUSSION}

The racial, facial, and skeletal characteristics of the patient play a critical role in orthodontic treatment planning. With the increasing number of Emirates seeking professional treatment from orthodontists, maxillofacial surgeons, or plastic and reconstructive surgeons, it has become apparent that there is a need to determine what constitutes a pleasing or normal face for the Emirates population. This study focused on samples of untreated Emirates subjects characterized as having normal occlusions and well-balanced faces. Young adults (19 to 25 years old) of both genders were included because most orthognathic surgeries are performed in this age group. Ninety one males and 85 females of Emirates origin were selected which allowed testing of the significance of gender difference to obtain more specific and useful cephalometric normative values. Extreme differences exist between normal and esthetically pleasing profiles, thus, normal occlusion, which is not necessarily related to beauty, was the main criterion used to select the subjects [42].

Not surprisingly, the gender dimorphism was found to be statistically significant for most of the cephalometric variables studied. All cranial base measurements as well as facial height were highly significant $(p<0.001)$ greater in Emirates males than females. This was in accordance to Bishara et al. [49]. Therefore Emirates males have larger cranial base dimensions than females whereas females had a steeper cranial base that was of high statistically significance $(p<0.001)$ than males. Emirates males also had tendency towards increased vertical jaw relationship, where total anterior facial height was significantly $(p<0.001)$ more than females. This would conclude that Emirates males have a tendency to be dolichofacial than Emirates females. These findings are in accordance with those of Scheidman et al. [13] Bishara and Fernandez [5] found significantly larger measurements for males in 3 skeletal linear parameters describing the anterior and posterior faces-N-ANS, N-Me, and S-Go. Miyajima et al. [15] indicated that, in a Japanese population, there were great skeletal differences between male and female subjects. Japanese women had more vertically 
Table 1. Comparison between cephalometric measurements of Emirates males and females.

\begin{tabular}{|c|c|c|c|c|c|c|}
\hline \multirow{2}{*}{ Variables } & \multicolumn{2}{|c|}{ Emirates males $(n=91)$} & \multicolumn{2}{|c|}{ Emirates females $(n=85)$} & \multirow{2}{*}{ t-test } & \multirow{2}{*}{$P$-value } \\
\hline & Mean & SD & Mean & SD & & \\
\hline \multicolumn{7}{|l|}{ Skeletal } \\
\hline $\mathrm{Ba}-\mathrm{N}(\mathrm{mm})$ & 88.95 & 3.51 & 71.54 & 1.60 & 4.94 & $<0.001^{* *}$ \\
\hline $\mathrm{S}-\mathrm{N}(\mathrm{mm})$ & 45.56 & 4.08 & 36.95 & 1.77 & 4.38 & $<0.001 * *$ \\
\hline $\mathrm{S}-\mathrm{Ar}(\mathrm{mm})$ & 135.35 & 5.57 & 112.17 & 3.89 & 3.88 & $<0.001^{* *}$ \\
\hline $\mathrm{FH}-\mathrm{SN}\left(^{\circ}\right)$ & 6.48 & 3.73 & 8.56 & 2.03 & -3.56 & $<0.001^{* *}$ \\
\hline $\mathrm{N}-\mathrm{Me}(\mathrm{mm})$ & 164.25 & 5.55 & 131.93 & 8.95 & 4.55 & $<0.001^{* *}$ \\
\hline N-ANS (mm) & 64.29 & 9.22 & 55.02 & 5.54 & 3.51 & $<0.001^{* *}$ \\
\hline ANS-Me(mm) & 87.07 & 3.63 & 68.44 & 8.69 & 4.83 & $<0.001^{* *}$ \\
\hline S-Go (mm) & 100.48 & 3.23 & 80.18 & 2.58 & 4.71 & $<0.001^{* *}$ \\
\hline $\mathrm{SGn}-\mathrm{FH}\left(^{\circ}\right)$ & 60.03 & 4.67 & 57.54 & 4.23 & 3.69 & $<0.001^{* *}$ \\
\hline $\operatorname{ANB}\left({ }^{\circ}\right)$ & 2.03 & 1.65 & 1.82 & 1.53 & 0.85 & $>0.05$ \\
\hline Ao-Bo /FH (mm) & 5.44 & 1.39 & 4.26 & 2.47 & 1.21 & $>0.05$ \\
\hline Ao-Bo (mm) & -0.47 & 2.46 & -1.31 & 2.66 & 2.21 & $<0.05^{*}$ \\
\hline $\mathrm{FH} / \mathrm{MP}\left({ }^{\circ}\right)$ & 25.44 & 4.54 & 23.17 & 6.01 & 2.38 & $<0.05^{*}$ \\
\hline MP-SN $\left({ }^{\circ}\right)$ & 31.95 & 6.47 & 31.71 & 6.11 & 0.26 & $>0.05$ \\
\hline SN-PP $\left({ }^{\circ}\right)$ & 5.77 & 3.77 & 7.87 & 3.17 & -4 & $<0.001 * *$ \\
\hline ANS Xi PM $\left({ }^{\circ}\right)$ & 45.36 & 3.90 & 42.61 & 4.75 & 4.18 & $<0.001^{* *}$ \\
\hline SNA $\left({ }^{\circ}\right)$ & 81.40 & 2.82 & 81.14 & 3.09 & 0.59 & $>0.05$ \\
\hline Co-A (mm) & 112.28 & 4.14 & 94.12 & 4.84 & 3.58 & $<0.001 * *$ \\
\hline $\mathrm{SNB}\left({ }^{\circ}\right)$ & 80.52 & 2.27 & 79.75 & 3.57 & 1.71 & $>0.05$ \\
\hline Pog-N vert (mm) & -4.23 & 1.57 & -1.95 & 3.34 & -2.16 & $<0.05^{*}$ \\
\hline Co-Gn (mm) & 156.03 & 5.84 & 128.10 & 5.02 & 4.10 & $<0.001^{* *}$ \\
\hline \multicolumn{7}{|l|}{ Dental } \\
\hline $\mathrm{U} 1-\mathrm{L} 1\left(^{\circ}\right)$ & 120.01 & 9.38 & 121.08 & 6.87 & -0.52 & $>0.05$ \\
\hline UI-SN $\left(^{\circ}\right)$ & 111.49 & 6.80 & 108.63 & 6.31 & 2.89 & $<0.05^{*}$ \\
\hline $\mathrm{U} 1-\mathrm{NA}\left({ }^{\circ}\right)$ & 29.20 & 1.09 & 26.55 & 5.86 & 2.11 & $<0.05^{*}$ \\
\hline U1-NA (mm) & 7.64 & 2.43 & 6.05 & 2.23 & 2.71 & $<0.05^{*}$ \\
\hline L1-NB $\left({ }^{\circ}\right)$ & 29.82 & 5.39 & 28.58 & 5.09 & 1.57 & $>0.05$ \\
\hline L1-NB (mm) & 8.47 & 2.74 & 5.87 & 2.91 & 3.73 & $<0.001^{* *}$ \\
\hline L1-MP $\left({ }^{\circ}\right)$ & 96.73 & 5.46 & 96.66 & 7.40 & 0.07 & $>0.05$ \\
\hline \multicolumn{7}{|l|}{ Soft tissue } \\
\hline H-Angle & 14.56 & 4.46 & 12.98 & 3.84 & 2.51 & $<0.05^{*}$ \\
\hline Z-Angle & 74.08 & 8.99 & 78 & 7.89 & -3.06 & $<0.05^{*}$ \\
\hline $\mathrm{N}^{\prime} \mathrm{SnPog}{ }^{\prime}\left({ }^{\circ}\right)$ & 156.91 & 6.92 & 133.79 & 5.51 & 3.81 & $<0.001^{* *}$ \\
\hline $\mathrm{N}^{\prime} \mathrm{PnPog}{ }^{\prime}\left({ }^{\circ}\right)$ & 127.48 & 4.78 & 136.85 & 8.03 & -4.64 & $<0.001^{* *}$ \\
\hline $\operatorname{PnN}{ }^{\prime} S n\left({ }^{\circ}\right)$ & 19.99 & 2.22 & 20.73 & 6.29 & -1.01 & $>0.05$ \\
\hline Sn-Stos (mm) & 27.09 & 1.53 & 16.79 & 2.35 & 5.92 & $<0.001^{* *}$ \\
\hline Stoi-Sm (mm) & 25 & 2.49 & 21 & 5.86 & 6.56 & $<0.001^{* *}$ \\
\hline Ls-E line (mm) & -5.88 & 3.56 & -1.80 & 4.03 & -2.60 & $<0.05^{*}$ \\
\hline Li-E line (mm) & -2.23 & 4.41 & -1.32 & 4.42 & -1.36 & $>0.05$ \\
\hline Pog-Pog' (mm) & 14.50 & 7.12 & 11.48 & 7.24 & 2.79 & $<0.05^{*}$ \\
\hline Ls-SnPog' (mm) & 3.47 & 2.20 & 12.01 & 2.66 & -3.96 & $<0.001^{* *}$ \\
\hline Li-SnPog' (mm) & 3.72 & 2.68 & 11.74 & 2.16 & -3.80 & $<0.001^{* *}$ \\
\hline
\end{tabular}

$\mathrm{p}=$ Probability level, not significant. $=\mathrm{p}>0.05, *$ significant $=\mathrm{p} \leq 0.05, * *$ significant $=\mathrm{p} \leq 0.01, * * *$ highly significant $=\mathrm{p} \leq 0.001 . *$ Student $\mathrm{t}-\mathrm{test}$.

oriented facial axis angles, greater mandibular plane angles, and smaller midfacial lengths, and they were more protrusive relative to the nasion perpendicular.

Regarding facial growth pattern, the Y-axis with $\mathrm{FH}$ plane angle was significantly greater $(p<0.001)$ in males. Therefore, Emirates males have more tendency to vertical growth pattern (backward mandibular rotation) than Emirates females as further evidenced by the significant $(p<0.05)$ increase of FMA and the high significant $(p<0.001)$ increase of ANS Xi PM angle. These findings are agreed with those of Park et al. [37] and Bishara et al. [49]. Accordingly, the results again explain the tendency of Emirates males to be more dolichofacial than females. 
No significant difference was found between males and females regarding the angular and linear measurements of the anteroposterior jaw relationship. These findings are agreed with those of Park et al. [37]. Whereas, Wits appraisal was significantly greater $(\mathrm{p}<$ 0.05 ) in males which could be attributed to the steeper maxilla in females as evidenced by SN-PP $\left(^{\circ}\right)$, rather than discrepancy between upper and lower jaws. Maxillary and mandibular anteroposterior positions was slightly more in males but of no significance but the chin position was significantly $(\mathrm{p}<0.05)$ more retruded in males (Pog-Nv mm). Thus, regarding skeletal facial convexity, Emirates males have more convex profiles than females, due to retruded chin, rather than retrognathic mandible or prognathic maxilla. These findings are also disagreed with those of Park et al. [37] and Scheidman et al. [11]. Moreover, maxillary and mandibular sagittal lengths were highly significantly $(p<$ 0.001) longer in Emirates male than females. These findings disagreed with those of Scheidman et al. [11]. This increase in size of jaws in males is coincident with their larger skeletal features of skull than Emirates females.

Concerning dental measurements, Emirates males showed significantly $(p<0.05)$ more proclined upper and lower incisors than females as indicated by the relationship of the maxillary and mandibular incisors to the SN, MP, NA, and NB lines. So, Normal angulation of incisors should be taken into consideration, when incisor retraction is planned in orthodontic treatment of Emirates adults.

In their study, Swlerenga et al. [36] found that Mexican American males and females have greater mandibular incisor proclination than black American or white children, and that maxillary incisor inclination of Mexican American women is more retroclined than that of black or white women. Miyajima et al. [25] found mandibular dentoalveolar protrusion in the Japanese men compared with European-American adults. No statistically significant gender dimorphism was found in the dental measurements of both Anatolian Turkish [42] and Japanese adults [25].

Most probably the soft tissue follows hard tissue structures, but could also consolidate them. Regarding soft tissue measurements, Emirates males had significantly greater $(p<0.001)$ soft tissue profile angle (N'Sn'Pog') than females whereas females had more (p $<0.05$ ) soft tissue convexity (N'Pn Pog') than males. In spite of retruded bony chin, the soft tissue chin (Pog') was more protruded in males than females, ranging from significant to highly significant. Emirates females had slightly more prominent noses than males, but of no significance. Accordingly, considering soft tissue profile, females had more convex facial profiles than males, while skeletally males had more convex profiles than females. Upper and lower lip lengths were significantly $(p<0.001)$ increased in males than females. These findings are in accordance with those of Hashim and AlBarakati [57] and Scheidman et al. [11]. This was attributed to the greater facial height in males and more to the increased lower facial height. The soft tissue of lip followed the hard tissue of upper and lower jaws. Also regarding the lip appearance, upper and lower lips were more protrusive in Emirates males than females. This was assured by significant $(p<0.05)$ increase of $\mathrm{H}$-angles, and decreased $\mathrm{Z}$ angle in Emirates males. These findings are disagreed with those of Eraby et al. [39]. The lip protrusion followed the difference in protrusion of upper and lower incisors. But on using the E-plane as reference for analyzing lip protrusion, the lips appeared more retrusive in Emirates males. This could be contributed more to soft tissue chin protrusion in males, rather than the actual lips' procumbency.

Along with the clinical examination and other patient records, knowledge of normative cephalometric values of normal samples from different ethnic groups can be helpful for planning orthodontic or orthognatic surgery. However, these normal data should not be used as a template. Orthodontic and orthognathic treatment should always be planned according to each patient's needs and desires. From the previous findings it is recommended to use the lateral cephalometric norms of the present study as a reference for orthodontic diagnosis and treatment planning of Emirates adults, separate for gender.

\section{CONCLUSIONS}

Emirates adults have distinct cephalometric features, which should be used as a reference in treating Emirates orthodontic patients.

Skeletally, Emirates adult males showed longer total, anterior, and posterior cranial base lengths, indicating larger cranial base; longer facial heights, greater vertical jaw relation (more tendency to be dolichocephalic),and longer midfacial and mandibular lengths than females.

Dentally, Emirates adult males demonstrated more proclined upper and lower incisors than females.

Considering soft tissue profile, Emirates females had more convex facial profiles than males, while skeletally males had more convex profiles than females.

Emirates males had greater upper and lower lip lengths and soft tissue profile angle due to a greater soft tissue chin thickness, whereas females had a greater soft tissue profile convexity due to greater nasal prominence.

The results of the present study support the view that the norms of specific population should be used as reference for successful orthodontic treatment and not ap- 
plied to different populations.

\section{REFERENCES}

[1] Broadbent, B.H. (1931) A new X-ray technique and its application to orthodontia. Angle Orthodontist, 1, 45-66.

[2] Hofrath, H. (1931) Die bedeutung der roentgenfern der kiefer anomalien. Fortschr Orthodontic, 1, 232-248.

[3] Athanasiou, A. (1997) Orthodontic cephalometry. MosbyWolfe, London.

[4] Bishara, S.E., Jacobsen, J.R., Hession, T.J. and Treder, J.E. (1998) Soft tissue profile changes from 5 to 45 years of age. American Journal of Orthodontics \& Dentofacial Orthopedics, 114, 698-706. doi:10.1016/S0889-5406(98)70203-3

[5] Bishara, S.E. and Fernandez, A.G. (1985) Cephalometric comparisons of the dentofacial relationships of two adolescent populations from Iowa and Northern Mexico. American Journal of Orthodontics, 88, 314-322. doi:10.1016/0002-9416(85)90131-9

[6] Downs, W.B. (1956) Analysis of the dentofacial profile. Angle Orthodontist, 26, 191-212.

[7] Downs, W.B. (1948) Variation in facial relationships: Their significance in the treatment and prognosis. American Journal of Orthodontics, 34, 812-840.

[8] Riedel, R.A. (1952) The relation of maxillary structures to cranium in malocclusion and in normal occlusion. Angle Orthodontist, 22, 142-145.

[9] Steiner, C.C. (1953) Cephalometrics for you and me. American Journal of Orthodontics, 39, 729-755. doi:10.1016/0002-9416(53)90082-7

[10] Bishara, S.E. (1981) Longitudinal cephalometric standards from 5 years of age to adulthood. American Journal of Orthodontics 1981, 79, 35-44.

[11] Scheideman, G.B., Bell, W.H., Legan, H.L., Finn, R.A. and Reisch, J.S. (1980) Cephalometric analysis of dentofacial normals. American Journal of Orthodontics, 78, 404-420.

[12] Argyropoulos, E. and Sassouni, V. (1989) Comparison of the dentofacial patterns for native Greek and American-Caucasian adolescents. American Journal of Orthodontics \& Dentofacial Orthopedics, 95, 238-249.

[13] Franchi, L., Baccetti, T. and McNamara, J.A. Jr. (1998) Cephalometric floating norms for North American adults. Angle Orthodontist, 68, 497-502.

[14] Farkas, L.G., Tompson, B., Phillips, J.H., Katic, M.J. and Cornfoot, M.L. (1999) Comparison of anthropometric and cephalometric measurements of the adult face. Journal of Craniofacial Surgery, 10, 18-25.

[15] Huang, W.J., Taylor, R.W. and Dasanayake, A.P. (1998) Determining cephalometric norms for Caucasians and African Americans in Birmingham. Angle Orthodontist, 68, 503-512.

[16] Drummond, R.A. (1968) A determination of cephalometric norms for the Negro race. American Journal of Orthodontics, 54, 670-682. doi:10.1016/0002-9416(68)90018-3

[17] Fonseca, R.J. and Klein, W.D. (1978) A cephalometric evaluation of American Negro women. American Journal of Orthodontics, 73, 152-160. doi:10.1016/0002-9416(78)90185-9
[18] Cotton, W.N., Takano, W.S. and Wong, W. (1951) The Downs analysis applied to three other ethnic groups. Angle Orthodontist, 21, 213-220.

[19] Richardson, E.R. (1980) Racial differences in dimensional traits of the human face. Angle Orthodontist, 50, 301-311.

[20] Kapila, S. (1989) Selected cephalometric angular norms in Kikuyu children. Angle Orthodontist, 59, 139-144.

[21] Jacobson, A. (1978) The craniofacial skeletal pattern of the South African Negro. American Journal of Orthodontics, 73, 681-691. doi:10.1016/0002-9416(78)90229-4

[22] Bacon, W., Girardin, P. and Turlot, J.C. (1983) A comparison of cephalometric norms for the African Bantu and a Caucasoid population. European Journal of Orthodontics, 5, 233-240.

[23] Anderson, A.A., Anderson, A.C., Hornbuckle, A.C. and Hornbukle, K. (2000) Biological derivation of a range of cephalometric norms for children of African American descent (after Steiner). American Journal of Orthodontics \& Dentofacial Orthopedics, 118, 90-100.

[24] Bailey, K.L. and Taylor, R.W. (1998) Mesh diagram cephalometric norms for Americans of African descent. American Journal of Orthodontics \& Dentofacial Orthopedics, 114, 218-223.

[25] Miyajima, K., McNamara, J.A. Jr, Kimura, T., Murata, S. and Iizuka, T. (1996) Craniofacial structure of Japanese and European-American adults with normal occlusions and well-balanced faces. American Journal of Orthodontics \& Dentofacial Orthopedics, 110, 431-438.

[26] Engel, G. and Spolter, B.M. (1981) Cephalometric and visual norms for a Japanese population. American Journal of Orthodontics, 80, 48-60.

[27] Kondo, S., Wakatsuki, E. and Shibagaki, H. (1999) A somatometric study of the head and face in Japanese adolescents. Okajimas Folia Anatomica Japonica, 76, 179-185.

[28] Alcalde, R.E., Jinno, T., Pogrel, M.A. and Matsumura, T. (1998) Cephalometric norms in Japanese adults. Journal of Oral and Maxillofacial Surgery, 56, 129-134.

[29] Ioi, H., Nakata, S., Nakasima, A. and Counts, A.L. (2007) Comparison of cephalometric norms between Japanese and Caucasian adults in antero-posterior and vertical dimension. European Journal of Orthodontics, 29, 493-499. doi:10.1093/ejo/cjm059

[30] Yen, P.K.J. (1973) The facial configuration in a sample of Chinese males. Angle Orthodontist, 43, 301-304.

[31] Cooke, M.S. and Wei, S.H.Y. (1988) Cephalometric "standards" for the southern Chinese. European Journal of Orthodontics, 10, 264-272.

[32] Lew, K.K., Ho, K.K., Keng, S.B. and Ho, K.H. (1992) Soft tissue cephalometric norms in Chinese adults with esthetic facial profiles. Journal of Oral and Maxillofacial Surgery, 50, 1184-1190. doi:10.1016/0278-2391(92)90151-O

[33] Wu, J., Hagg, U. and Rabie, A.B. (2007) Chinese norms of McNamara's cephalometric analysis. Angle Orthodontist, 77, 12-20. doi:10.2319/021606-62R.1

[34] Obloj, B., Fudalej, P. and Dudkiewicz, Z. (2008) Cephalometric standards for Polish 10-year-olds with normal occlusion. Angle Orthodontist, 78, 262-269. doi:10.2319/011207-14.1 
[35] Moldez, M.A., Sato, K., Sugawara, J. and Mitani, H. (2006) Linear and angular Filipino cephalometric norms according to age and gender. Angle Orthodontist, 76, 800805.

[36] Swierenga, D., Oesterle, L.G. and Messersmith, M.L. (1994) Cephalometric values for adult Mexican Americans. American Journal of Orthodontics \& Dentofacial Orthopedics, 106, 146-155. doi:10.1016/S0889-5406(94)70032-X

[37] Park, I., Bowman, D. and Klapper, L. (1989) Cephalometric study of Korean adults. American Journal of Orthodontics \& Dentofacial Orthopedics, 96, 54-59. doi:10.1016/0889-5406(89)90229-1

[38] Hwang, H.S., Kim, W.S. and McNamara, J.A. Jr. (2002) Ethnic differences in the soft tissue profile of Korean and European-American adults with normal occlusions and well-balanced faces. Angle Orthodontist, 72, 72-80.

[39] Erbay, E.F., Canikliog lu, C.M. and Erbay, S.K. (2002) Soft tissue profile in Anatolian Turkish adults: Part I. Evaluating of horizontal lip position using different soft tissue analyses. American Journal of Orthodontics \& Dentofacial Orthopedics, 121, 57-64. doi:10.1067/mod.2002.119780

[40] Erbay, E.F. and Canikliog`lu, C.M. (2002) Soft tissue profile in Anatolian Turkish adults: Part II. Comparison of different soft tissue analyses in the evaluation of beauty. American Journal of Orthodontics \& Dentofacial Orthopedics, 121, 65-72. doi:10.1067/mod.2002.119573

[41] Basciftci, F.A., Uysal, T. and Buyukerkmen, A. (2003) Determination of Holdaway soft tissue norms in Anatolian Turkish adults. American Journal of Orthodontics \& Dentofacial Orthopedics, 123, 395-400. doi: $10.1067 / \bmod .2003 .139$

[42] Basciftci, F.A., Uysal, T. and Buyukerkmen, A. (2004) Craniofacial structure of Anatolian Turkish adults with normal occlusions and well-balanced faces. American Journal of Orthodontics \& Dentofacial Orthopedics, 125, 366-372. doi:10.1016/i.ajodo.2003.04.004

[43] Nanda, R. and Nanda, R.S. (1969) Cephalometric study of the dentofacial complex of North Indians. Angle Orthodontist, 39, 22-28.

[44] Cerci, V., Martins, J.E. and de Oliveira, M.A. (1993) Cephalometric standards for white Brazilians. The International Journal of Adult Orthodontics \& Orthogathic Surgery, 8, 287-292.

[45] Evanko, A.M., Freeman, K. and Cisneros, G.J. (1997) Mesh diagram analysis: Developing a norm for Puerto Rican Americans. Angle Orthodontist, 67, 381-388.

[46] Hajighadimi, M., Dougherty, H.L. and Garakani, F. (1981) Cephalometric evaluation of Iranian children and its comparison with Tweed's and Steiner's standards. American Journal of Orthodontics, 79, 192-197. doi:10.1016/0002-9416(81)90317-1

[47] Loutfy, M.S., Ponitz, P. and Harris, J.E. (1971) Cepha- lometric standards for normal Egyptian face. Egyptian Dental Journal, 17, 91-100.

[48] Shehata, F.I. (1982) Bimaxillary prognathism in the Nubian people of Egypt. Angle Orthodontist, 52, 19-25.

[49] Bishara, S.E., Abdalla, E.M. and Hoppens, B.J. (1990) Cephalometric comparisons of dentofacial parameters between Egyptian and North American adolescents. American Journal of Orthodontics \& Dentofacial Orthopedics, 97, 413-421.

[50] Mouakeh, M. (2001) Cephalometric evaluation of craniofacial pattern of Syrian children with Class III malocclusion. American Journal of Orthodontics \& Dentofacial Orthopedics, 119, 640-649.

[51] Hamdan, A.M. and Rock, W.P. (2001) Cephalometric norms in an Arabic population. Journal of Orthodontics, 28, 297-300.

[52] Shalhoub, S.Y., Sarhan, O.A. and Shaikh, H.S. (1987) Adult cephalometric norms for Saudi Arabians with a comparison of values for Saudi and North American Caucasians. British Journal of Orthodontics, 14, 273-279.

[53] Sarhan, O.A. and Nashashibi, I.A. (1988) A comparative study between two randomly selected samples from which to derive standards for craniofacial measurements. Journal of Oral Rehabilitation, 15, 251-255.

[54] Al-Jasser, N.M. (2000) Cephalometric evaluation of craniofacial variations in normal Saudi population according to Steiner analysis. Saudi Medical Journal, 21, 746-750.

[55] Al-Jame, B., Artun, J., Al-Azemi, R., Behbehani, F. and Buhamra, S. (2006) Lateral cephalometric norms for adolescent Kuwaitis: Hard tissue measurements. Medical Principles and Practice, 15, 91-97. doi:10.1159/000090910

[56] Hassan, A.H. (2006) Cephalometric norms for Saudi adults living in the western region of Saudi Arabia. Angle Orthodontist, 76, 109-113.

[57] Hashim, H.A. and AlBarakati, S.F. (2003) Cephalometric soft tissue profile analysis between two different ethnic groups: A comparative study. Journal of Contemporary Dental Practice, 2, 60-73.

[58] Al-Gunaid, T., Yamada, K., Yamaki, M. and Saito, I. (2007) Soft-tissue cephalometric norms in Yemeni men. American Journal of Orthodontics \& Dentofacial Orthopedics, 132, e7-e14.

[59] Molhave, A. (1958) Sitting and standing posture in man. Ugeskr Laeger, 120, 1516-1518.

[60] Solow, B. and Tallgren, A. (1971) Natural head position in standing subjects. Acta Odontologica Scandinavica, 29, 591-607.

[61] Siersbaek-Nielsen, S. and Solow, B. (1982) Intra- and interexaminer variability in head posture recorded by dental auxiliaries. American Journal of Orthodontics, 82, 50-57. 